\title{
Beyond Subsistence: Cultural Usages and Significance of Baler Shells in Philippine Prehistory
}

\author{
Timothy Vitales, National Museum of the Philippines
}

\section{Introduction}

For apparent reasons, Molluscan remains constitute a very large portion of materials recovered from archaeological sites in the Indo-Pacific. The tropical Indo-Pacific biogeographic region has the largest diversity of marine molluscs in the world (Vermeij 1993); however, despite the variety of molluscan species, only certain taxa were significantly collected for food consumption and for shellworking and utilisation. Some of the taxa collected for the manufacture of artefacts include species in the Tridacnidae (giant clams), Trochidae (top shells), Turbinidae (turban shells), Conidae (cone shells), Pteriidae (Pinctada spp. pearl oysters), and Volutidae (volute and baler shells) families (Szabó 2005, 2008).

Baler shells (genus Melo) represent the largest members of family Volutidae, with sizes ranging from 175 to almost $470 \mathrm{~mm}$ in length (Weaver and DuPont 1970). These marine gastropods are characterised by their inflated ovate shell, elongated but wide aperture, large dome-shaped protoconch (hidden or exposed), and thick folds in the columella. There are seven known species patchily distributed from the eastern Indian Ocean to the western Pacific Ocean, generally living on mud-sand substrates in littoral and sublittoral zones (Springsteen and Leobrera 1986; Weaver and DuPont 1970). These molluscs are edible and are used extensively as raw materials, as seen from ethnographic accounts in Australia, Papua New Guinea, and some regions in Southeast Asia, being fashioned into different objects, such as containers (Chen 1969; McCarthy 1967; McCarthy and Seltzer 1960; Schall 1985 in Smith and Veth 2004; Thomson 1934), valuable adornments (Akerman 1973; Hughes 1977; Mulvaney and Kamminga 1999; Przywolnik 2003), and tools (Akerman 1975; Schall 1985 in Smith and Veth 2004; Tindale 1977).

The widespread presence of baler shell remains in the archaeological record attests to a long history of exploitation in the Indo-Pacific (Figure 1). The earliest evidence to date comes from northwest Australia, as early as 32,000 years ago in Mandu Mandu Creek Rockshelter, Northwest 
Cape (Morse 1993; O'Connor and Veth 2000). Other sites include Sumatra (van Heekeren 1972), Sarawak (Szabó et al. 2008), Vietnam (Szabó unpublished data), and the Philippines (Fox 1970; Vitales 2009a), ranging from 10,000 years to as recently as 500 years ago.

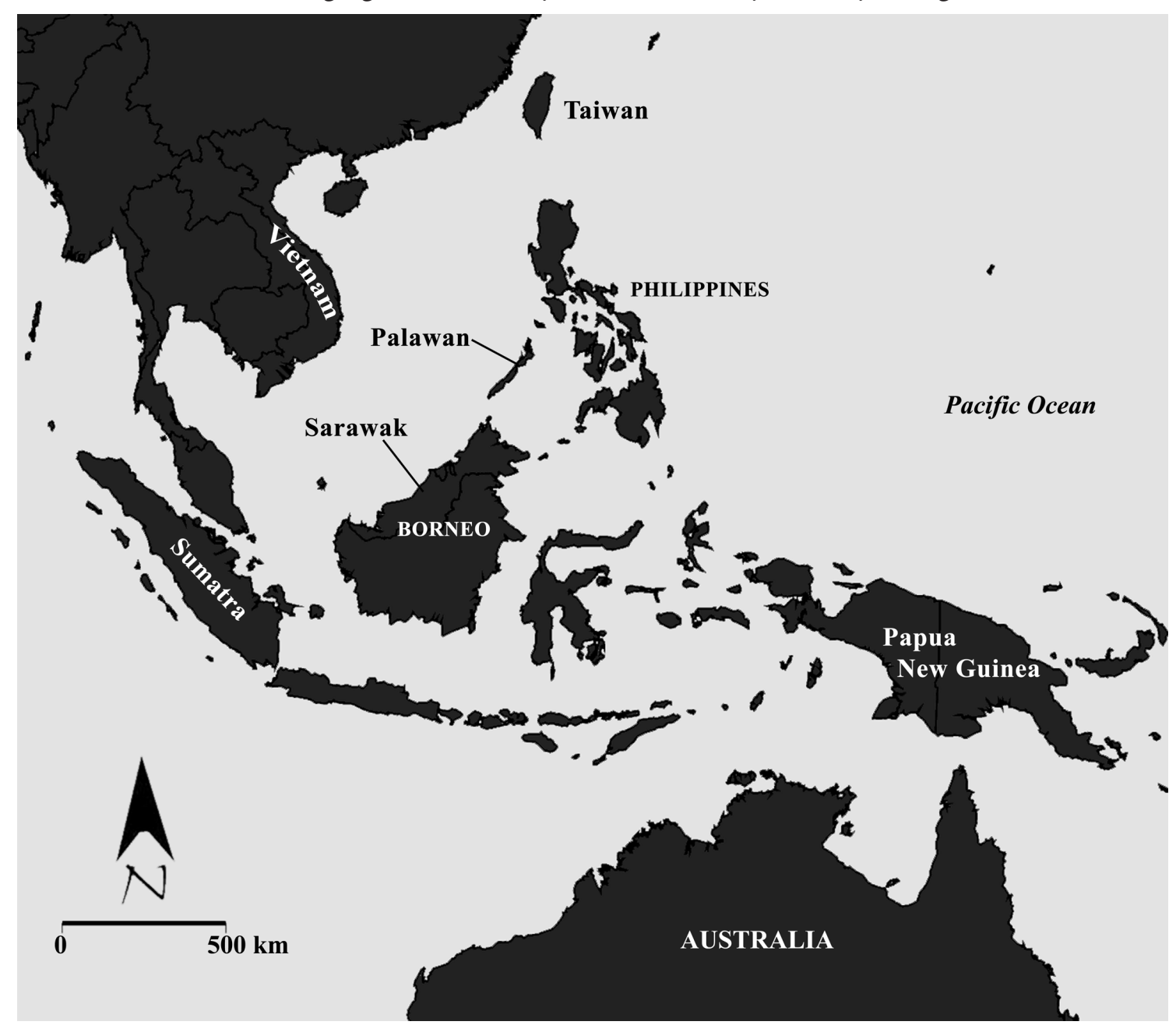

Figure 1. The Indo-Pacific and the Philippines.

Source: Modified from http://commons.wikimedia.org/wiki/File:Se_asia_malaysia.png

This paper will focus on the long history of baler shell exploitation and their significance in Philippine prehistory. The primary data used in this study comes from the baler shell assemblage recovered from the excavations in Ille Cave and Rockshelter site in northern Palawan, western Philippines. Ille Cave and Rockshelter, located in the eastern part of El Nido, Palawan (Figure 2 ), is a multi-phase site, with evidence of cave utilisation ranging from periods as early as the terminal Pleistocene to as late as the 18 ${ }^{\text {th }}$ century (Lewis et al. 2006; Lewis et al. 2008; Paz et al. 2008; UP-ASP 2005-2006). A majority of the materials investigated in this paper come from a shell midden deposit, with associated artefacts from the Neolithic and Metal Ages, such as decorated and undecorated pottery, polished stone adzes, and various worked shells. Human remains were also found at these levels, indicating the cave was also used for burial purposes during these periods. However, evidence of continuous reworking of most parts of the site has blurred the distinction between the Neolithic and Post-Neolithic (Metal Age to $18^{\text {th }}$ century), subsistence-related deposits (e.g., shell midden (see Faylona 2003, 2008)), and burial deposits. 
Nevertheless, they will still constitute the samples to be studied in this paper; since the author will be investigating the nature of the baler shell remains found in Ille, whether they mainly represent evidence of marine resource-based subsistence or evidence of artefact production and utilisation.

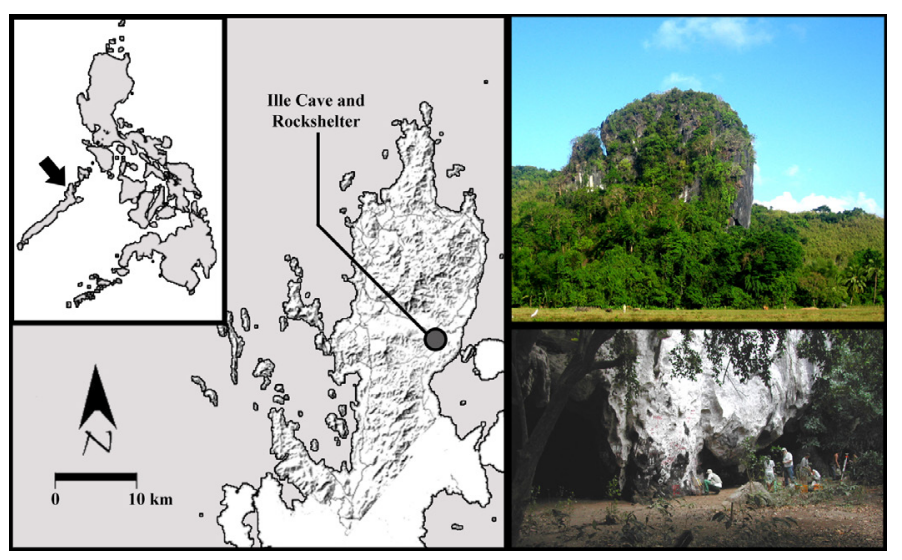

Figure 2.The location of the Ille Cave and Rockshelter site in the Philippine map (inset) and northern Palawan map (left). The site is located at the base of a karst tower (above right) and is composed of two major cave entrances (below right).

Source: Philippines map modified from http://www.palawanjoe.com/images/elnido_map2.jpg Ille tower on top right photo by author; Ille cave on bottom right photo by Victor Paz.

\section{Baler Shell Remains in Philippine Sites}

The Philippine archipelago has very rich archaeological evidence of baler shell exploitation and use; on current evidence, the richest in the Indo-Pacific region. Around thirty recorded sites within the archipelago have Melo remains, mostly located in the central and southern Philippines (Figure 3). The densest concentration of baler shells from archaeological sites is centred on the Palawan region, known for its rich diversity of shell artefact forms, and dubbed a 'major shellworking community of practice' (Szabó 2005). The notable concentrations of baler shell remains in Palawan are on Coron Island (3 sites) (Guthe n.d.; Solheim 1964, 2002), El Nido (12 sites) (Fox 1970, 1977; Paz 1998; Paz et al. 2008; Solheim 2004; Szabó 2005; UP-ASP 2005-2006; Vitales 2009a), and Quezon (5 sites) (Fox 1970; Kress 2000). Aside from Palawan, other sites with a presence of baler shells include the Bicol region of Luzon (Fox and Evangelista 1956, 1957), Bondoc Peninsula in Quezon Province, Luzon (UP-ASP unpublished data; Vitales 2009b), and the islands of Masbate (Solheim 1964, 2002), Samar (Guthe n.d.; Santiago and Barbosa 1977), Bohol (Roales 1985), Cebu (ACECI 2006; Nishimura 1992), and Saranggani Province in southern Mindanao (Dizon and Santiago 1996). Remains of baler shells found in Philippine sites generally range from the Neolithic Period around 4,000 years ago to as recent as 400 to 500 years ago (Vitales 2009a), although there are some baler shell fragments believed to date as early as c. 10,000 to 12,000 years ago at Ille Cave and Rockshelter in El Nido, Palawan (P. Piper pers. comm. 2006).

The species of baler shell identified from Philippine sites are given as Melo aethiopica (identified as Cymbium aethiopicum in Solheim's study, which is a junior synonym of $M$. aethiopica, for the baler shell artefacts from the Guthe collection (Solheim 1964, 2002)), Melo amphora (originally identified as Melo diadema, which is a junior synonym of M. amphora (Fox 1970, 1977; Kress 2000; Szabó 2005)), and Melo broderipii (ACECI 2006; Szabó 2005). Reassessment of these baler shell remains by Vitales (2009a) identified most of them as Melo broderipii. 


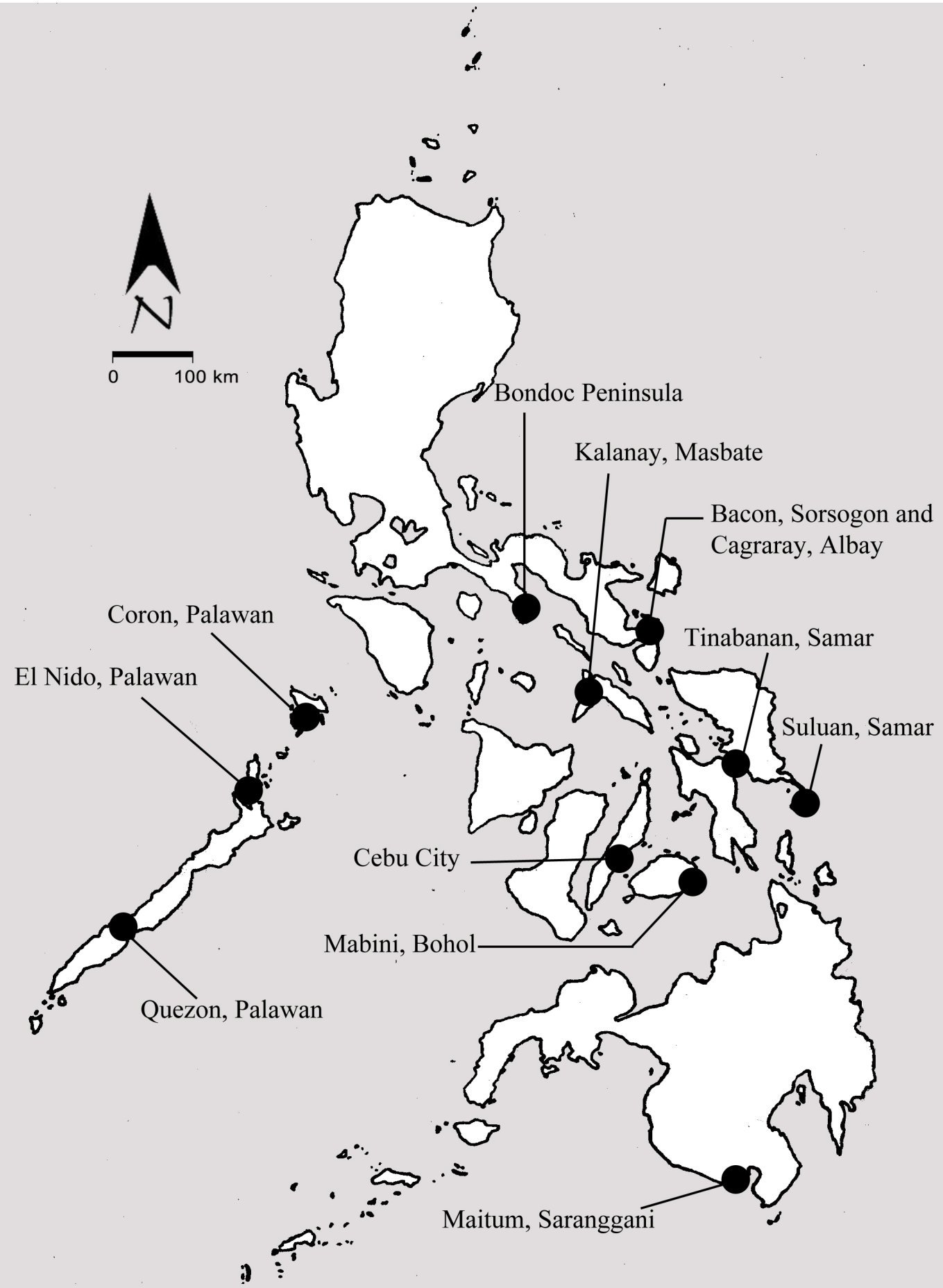

Figure 3. Map of the Philippines showing the sites with reported baler shell remains.

Source: Archaeological Studies Program (ASP), University of the Philippines.

\section{Analytical Framework}

The Melo shell assemblage in the Ille site is mostly composed of fragments, although there were baler shell remains found that are evidently whole artefacts, so these will be considered as well. Total identification (distinguishing between other molluscan fragments) and recovery of 
baler shell remains were done during the excavation. As for the fragments, each will be initially identified according to which part of the shell it corresponds to (Figure 4). The identification will be divided into six categories:

- apical - composed mainly of spire and shoulder

- basal - composed mainly of siphonal canal, sometimes with basal part of lip and exterior columellar folds

- body whorl fragments - composed mainly of the dorsal and/or ventral face

- lip fragments

- apical and basal fragments - spire and siphonal canal connected through lip or partial body whorl

- columellar fragments - composed primarily of the inner structure of the shell
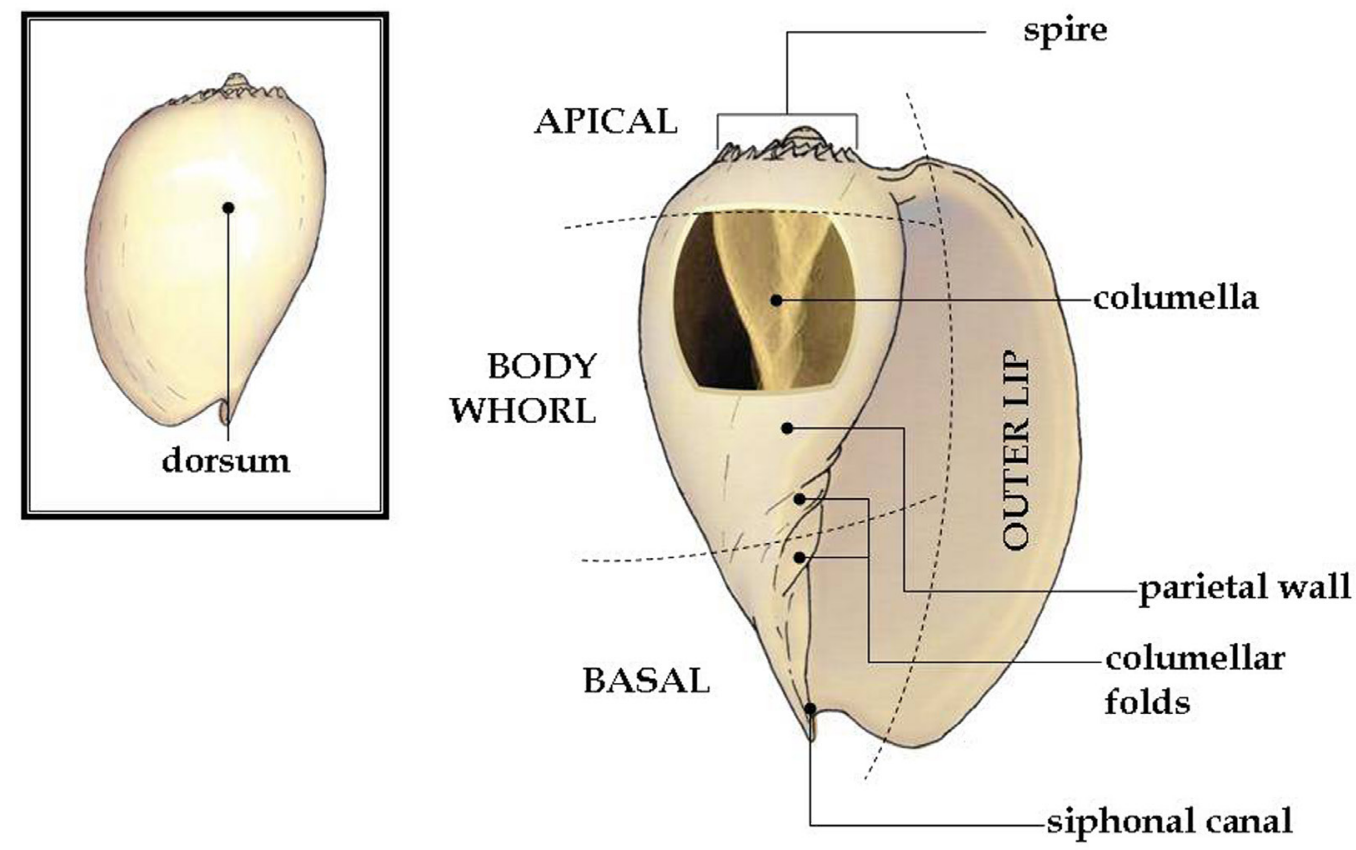

Figure 4. Six categories for identification of Melo shell.

Source: Timothy Vitales.

Individual fragments will be quantified as single specimens, although fragments that can be refitted will be counted as part of their aggregate specimen. Breakage patterns were also considered in the analysis using Szabo's (2005) method of distinguishing natural breakage, human-modified breakage related to subsistence, and human-modified breakage related to artefact production. The baler shell artefacts were analysed and classified according to their manner of working. Other variables were also considered, such as the surface condition of the shells and possible evidence of bioerosion, coral encrustation, and sponge borings, which would tell us whether the molluscs were collected fresh or post-mortem (Ibid.). Local knowledge from coastal communities that the author visited in the central Philippines regarding meat extraction from baler shells was also noted (although not systematically recorded) and served as a reference for identifying any subsistencerelated shell remains. 
Baler shell remains from other sites, particularly of the same period, were also analysed for comparative purposes. However, the baler shell remains found in later-period sites will be considered as well in order to understand the nature of its exploitation after the Neolithic and Metal Ages.

\section{Results of the Analysis}

\section{Food discard or artefact fragments?}

The question of whether there is evidence of purely subsistence-related baler shell remains can be addressed if we understand the processes of meat extraction of Melo spp. in the Philippines. Correspondence from the locals in Palawan, Cebu (central Philippines), and the Bicol region (eastern Philippines) reveals two methods of meat extraction. One involves hooking the meat and letting the shell naturally fall off onto to the ground. This is generally done when there is a desire to preserve the shell, which is sometimes used for decorative or commercial purposes. Another method of meat extraction for Melo spp. is by breaking through a large portion of the body whorl until the meat is accessible. With this method, the inner architecture of the shell usually remains intact, since breaking through the thin body whorl would be adequate for easily extracting the meat from the wide space inside the shell (Figure 5). It would seem unnecessary to break the thick columella in order to remove the meat. Based on local accounts, there is a possibility that similar meat extraction techniques were used in the past and, therefore, we should expect most parts of the shell, such as the body whorl, spire, columella, and basal portions, to be equally present in the site.

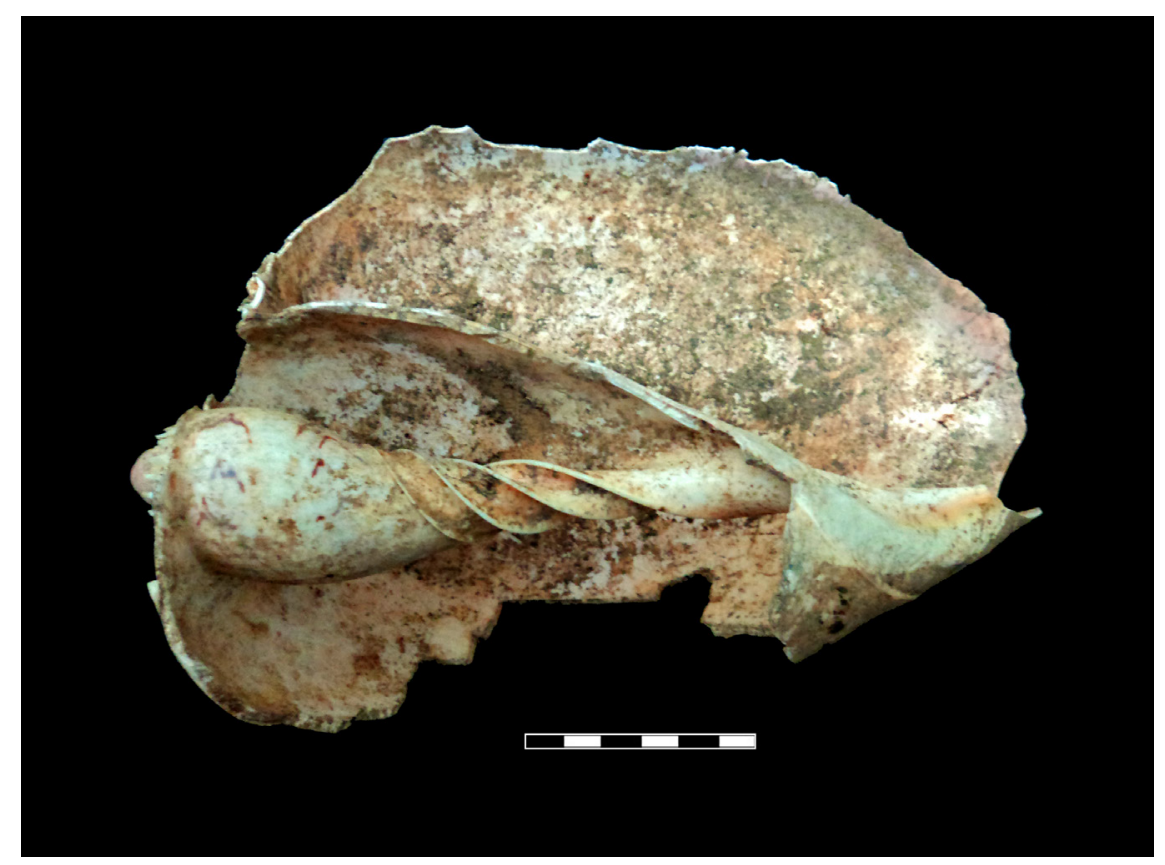

Figure 5. An example of a baler shell that was broken for meat extraction.

Source: Timothy Vitales.

The results of analysis of the Melo sp. fragments from Ille Cave (Figure 6) revealed that the shell parts recovered consist mainly of body whorl fragments (51\%), as well as several fragments of spire and shoulder (12\%), lip (10\%), and basal portions, such as the siphonal canal (10\%), with few apical-basal fragments (Figure 7). Only one columellar fragment, however, was recovered 
from the excavation. As for the body whorl fragments, it seems that only dorsal portions were found at the site. The ventral parts (characterised by the presence of a smooth parietal wall) were noticeably absent.

\section{Baler Shell Remains from Ille Cave and Rockshelter}

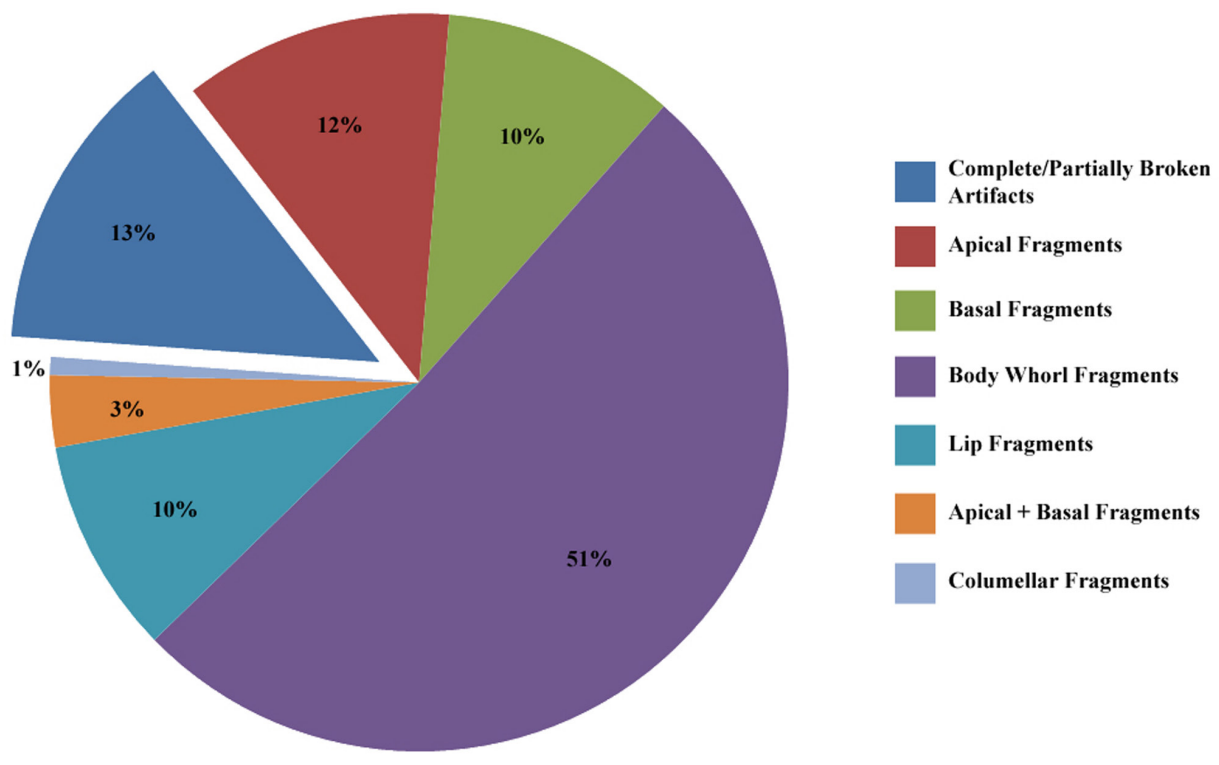

Figure 6. Percentages of identified baler shell artefacts and different fragments of baler shell remains found in Ille Cave and Rockshelter.

Source: Timothy Vitales.
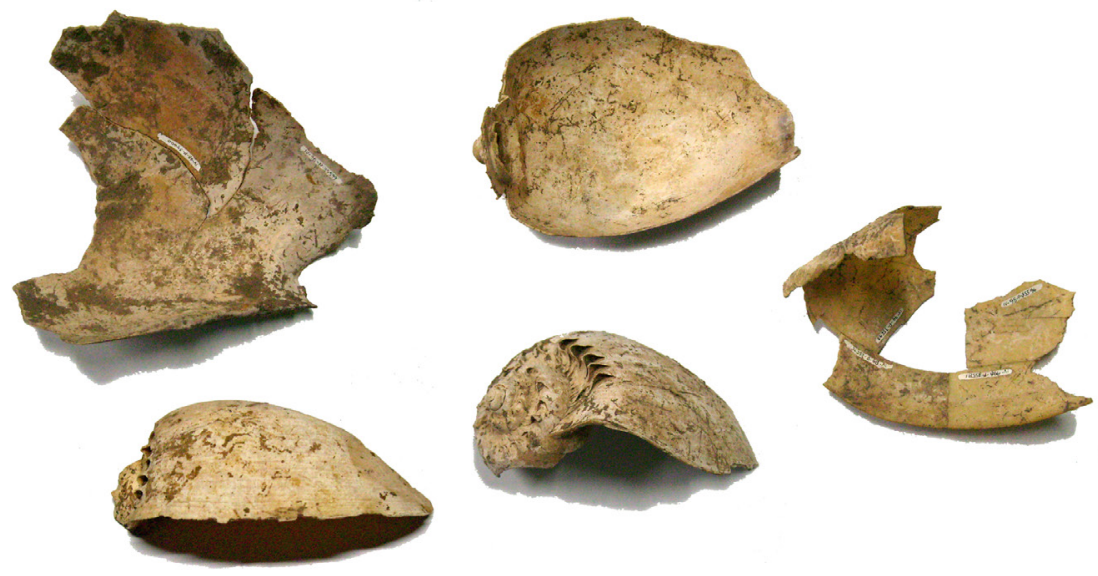

Figure 7. Examples of different baler shell fragments found in Ille site. Some of the fragments belong to one piece and were restored. Scale in centimetres.

Source: Timothy Vitales. 
The recognisable baler shell artefacts (complete and partially complete specimens), on the other hand, formed $13 \%$ of the total specimens. These artefacts resembled the 'scoop' forms similar to those described in previous literature on baler shell artefacts found in Palawan (see Alba 1998; Bautista 1988; Fox 1970; Szabó 2005). Three formal classes were observed in the artefact assemblage based on the type of working and the parts of the shells utilised (Figure 8) (Vitales 2009a):

- Class 1 - The ventral portions of the shell are removed, including the siphonal canal and columella, leaving a deep concave form composed only of the spire and dorsal surface of the body whorl. The worked edges ('rim') are smoothed and cut, while the spines are often abraded.

- Class 2 - Almost two-thirds of the shell is removed (including the spire and probably the lip), leaving a shallow concavity. Like Class 1 specimens, the worked edges are also cut, and the spines on the remaining shoulder are abraded.

- Class 3 - Only the ventral face of the body whorl and columella are removed, leaving a deep concave form like that of Class 1 specimens, but including the rest of the lip and siphonal canal. The worked edges are irregular and show evidence of chipping, possibly through pressure flaking or indirect percussion. The spines on the spire and shoulder do not display signs of human modification, unlike Classes 1 and 2.

Analysis of the breakage patterns on most of the fragments revealed evidence of working as well, particularly in the body whorl, shoulder, and siphonal canal parts of the shell. Evidence of chipping, snapping, and cutting was found on the broken edges, which seems to be a departure from the natural fractural tendencies of the shell. Furthermore, apical fragments also showed a total removal of the thick columella connecting the interior of the spires-clearly evidence of working.

The particular fragments found at the Ille site, such as the spire, dorsal portions of the body whorl, and basal portions, seem to constitute the parts of baler shells utilised in manufacturing scoop forms as described above. This was further confirmed by the near absence of the columella and ventral portions of the body whorl. The identified parts from the shell fragments showing evidence of working also corresponded to the worked portions of the Melo shell artefacts. It can also be argued that the dorsal fragments, which showed the least evidence of deliberate working, could be parts of these shell scoops, since the dorsum is the main part utilised. From this evidence, we can therefore infer that the baler shell assemblage recovered from the Ille site were most likely artefact fragments rather than purely subsistence-related. In addition, it indicates that the reduction processes for the production of these artefacts were done outside the site.

\section{Looking at other sites}

To get a general view of the patterns of exploitation of Melo spp. in Philippines prehistory, it will be important as well to examine the Melo shell remains recovered from other Philippine sites. I focused particularly on the Neolithic and Metal Age sites since most of the baler shell remains were found in association with these periods and were contemporaneous with the Ille assemblage. However, I also considered studying the baler shell remains recovered from later-period sites (around 1500 to 500 years ago) to see any probable changes or continuity in these patterns after the Neolithic and Metal Ages.

The Palawan region has the densest concentration of baler shell remains, dating from the Neolithic to the Metal Age. Like Ille, all of these sites were cave or rockshelter sites that contained burial deposits. Only two Palawan sites, however, contained significant amounts of subsistence-related 
deposits: Duyong Cave and Sa'gung Rockshelter from Quezon, southern Palawan. Neolithic midden deposits from Sa'gung Rockshelter have already been analysed by Kress (2000) and, so far, only one baler shell was identified in the molluscan assemblage. Initial examination identified the baler shell as worked for artefact purposes. The process of reduction was similar to those found in the Ille assemblage (removal of columella and ventral face). The Duyong shell midden analysis, on the other hand, has been included in Fox's (1970) monograph of the Tabon caves. The shells were mostly coastal marine, brackish, and freshwater species (see also Kress 2000) and no Melo spp. were identified from the assemblage, dated around 7000 years ago. There were, however, Melo shell remains on the upper levels of the excavation, not associated with the midden deposits. All of the baler shell specimens from Duyong were worked and were similar to the baler shell scoop forms from Ille. One specimen, in fact, still had an intact basal portion of the columella, similar to the columellar fragment recovered from Ille. It is likely, therefore, that this fragment is part of the artefact as well. The rest of the baler shell remains from other Palawan burial cave sites were worked and manufactured into scoop forms, with the exception of one unmodified sub-adult baler shell found in Tadyaw Cave in Quezon, southern Palawan.

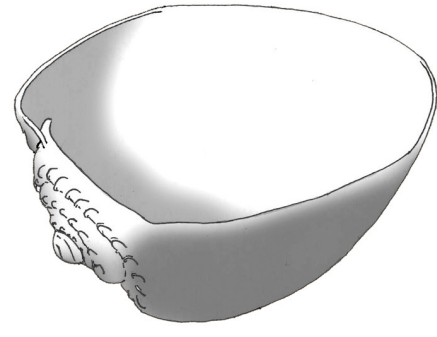

Class 1

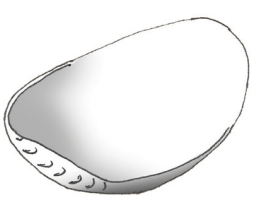

Class 2

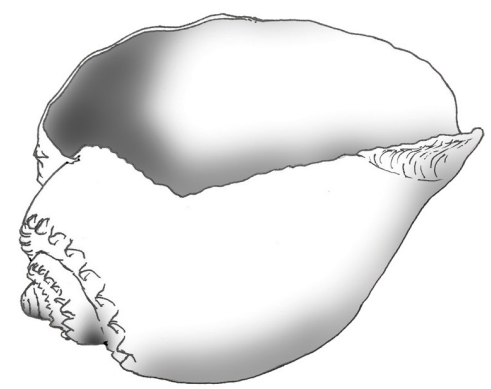

Class 3

Figure 8. The three class forms of baler shell 'scoops' generally found in Philippine archaeological sites.

Source: Timothy Vitales.

Aside from Palawan, other Neolithic and Metal Age sites containing baler shells were mostly burial cave sites; however, one site in the Bondoc Peninsula in southeastern Luzon was identified as an open midden and jar burial site (Paz et al. 2008). The baler shell remains recovered from the sites in the Bicol region (Fox and Evangelista 1956, 1957), Bondoc Peninsula (see Vitales 2009b), Bohol Island (Roales 1985), Saranggani Province (Dizon and Santiago 1996), and Samar (Guthe n.d.) were mostly worked and manufactured into scoop forms similar to the Palawan specimens. Maitum site in Saranggani Province, southern Philippines, on the other hand, seemed to have both worked and unworked shells, based on the initial examination of the zooarchaeological materials recovered from the site (Dizon and Santiago 1996). A seemingly unworked young Melo shell was recovered from a pot, while a Melo shell scoop, recovered from the surface in association with the Metal Age artefacts and burial jars. Another 'unworked' baler shell was recovered from an excavation of a cave site in Kalanay, Masbate, by Solheim $(1964,2002)$ and was associated with Metal Age deposits, including human remains.

Fewer baler shell remains were found in later-period sites. Only two later-period sites were known to have baler shell remains: Suluan Island in Samar, and Cebu City, both in the central Philippines. The baler shell found in a burial cave site in Suluan Island was a scoop artefact (Santiago and Barbosa 1977) similar to the scoop forms typically found in Neolithic and Metal 
Age sites in Palawan and other areas. However, the time-depth of the associated materials (deliberately modified skulls) placed the site between c. 10th century CE to c. 17th century CE. Cebu City, on the other hand, yielded baler shell remains at sites dating from the 16th to 18th centuries (ACECI 2006; Nishimura 1992). The earlier excavation of these sites (Nishimura 1992) mentioned the presence of Melo spp. in the midden deposits and no indication of shell working from this taxa. The recent excavation (ACECI 2006), however, has only one unworked Melo broderipii, also found in possible subsistence-related deposits.

\section{Evidence from the shell material}

Previous studies on molluscan exploitation in Philippine prehistory indicate subsistence and diet as primary reasons for its collection, with utilisation of the shell as a raw material for artefact manufacture being a secondary consideration (Alba 1998). Szabo's (2005) technological studies on worked shells in the Philippines, on the other hand, revealed the contrary. Evidence of certain worked shells, such as Conus spp., from post-mortem collections of molluscs were observed, indicating that they were collected mainly for artefact production and not primarily as a food source. Subsequently, physical examinations were also done on Melo shell remains to see if there was evidence of post-mortem collecting similar to the other worked shells analysed by Szabó.
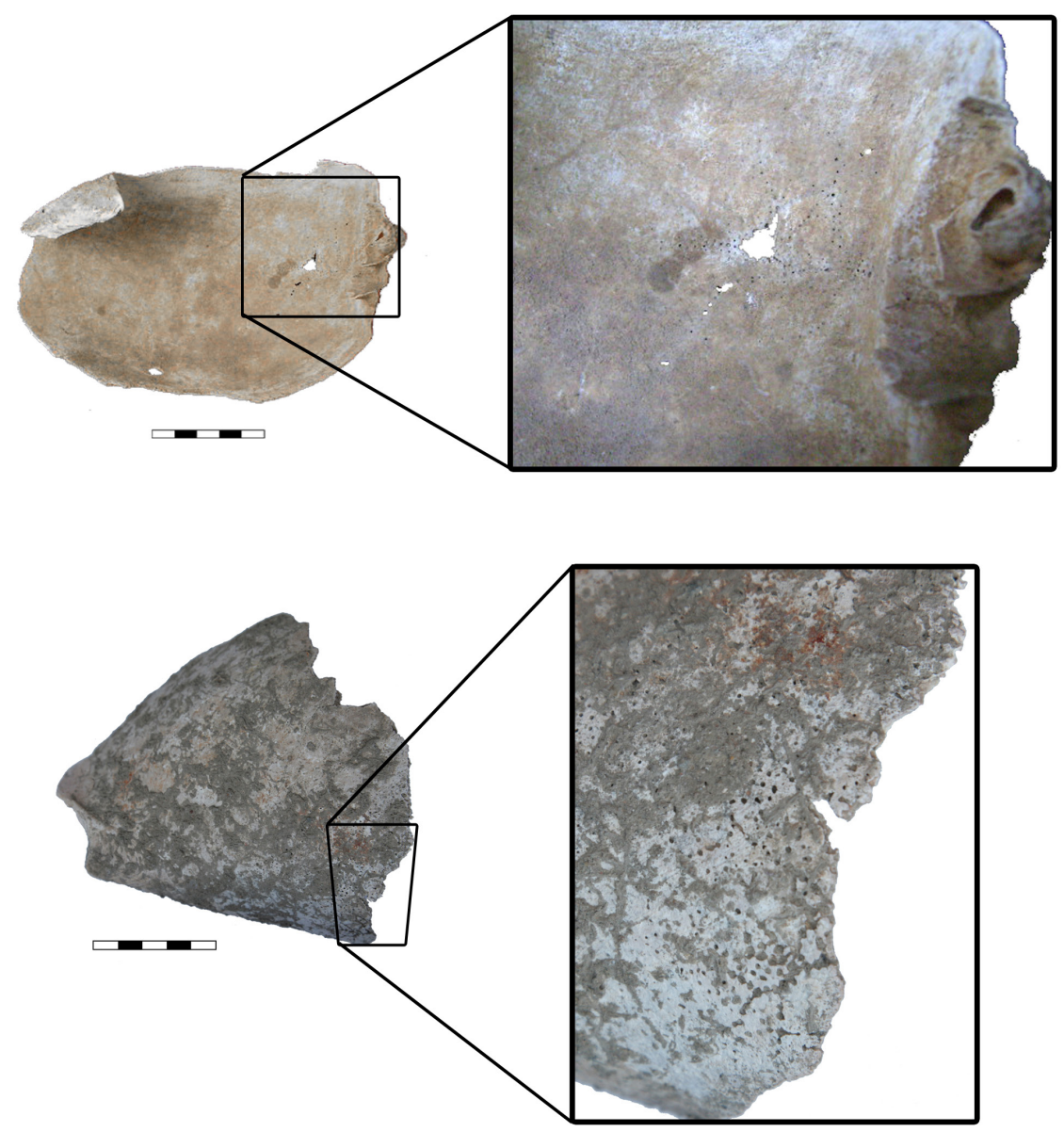

Figure 9. Baler shell scoop fragments from Batu Puti Cave in Quezon, Palawan (above) and from Ille Cave and Rockshelter (below) with evidence of animal borings. Scale in centimetres.

Source: Timothy Vitales. 
Virtually all of the worked Melo shells in Ille were most likely collected fresh; some, in fact, had retained their porcelaneous interior surface. However, there were two baler shell remains at the site that showed signs of post-mortem collecting. Animal borings, such as those made by clionid sponges, were seen on the interior surface of these remains, an indication that the baler shells were long dead before collection, manufacture, and deposit at the site (Figure 9). Baler shell remains from sites other than Ille were also examined, revealing at least three baler shells with evidence of post-mortem collection. Two of these were baler shell artefacts from Batu Puti Cave in Quezon, southern Palawan; one contained clionid borings on the interior surface, while the other was evidently water-worn prior to its manufacture and usage. The third specimen was an unworked baler shell from the later-period site in Cebu City. Evidence of calcareous encrustations and possible animal borings were found on the interior surface of the lip, clearly indicating the inhabitancy of a post-mortem deposit.

Based on the physical analysis of the baler shell remains, it seems that most of the Melo sp. molluscs were collected fresh and their meat most likely eaten. However, their collection as a food source was certainly not the end in itself. During the Neolithic to the Metal Ages, most of these shells were apparently manufactured into artefacts, which seemed to be the primary purpose for their acquisition. Evidence of post-mortem collections of some of the shells further supports this inference.

\section{Understanding the Significance of Baler Shells in Philippine Prehistory}

The abundance of baler shells from Neolithic and Metal Age sites in the central and southern Philippines, particularly in Palawan, clearly demonstrates the frequent and continuous exploitation of these gastropods in this region over the past 3000 years. The high occurrence of worked baler shells, along with evidence of post-mortem collecting, indicates that they were not primarily collected for subsistence purposes but, rather, for shell-working and utilisation. This evidence seems to signify the shell's cultural importance in the past.

\section{The mortuary role of baler shells}

The ubiquity of baler shell remains in burial cave sites from the Neolithic and the Metal Ages suggests that their occurrences somehow played an important role in mortuary practices during that particular period. The most conspicuous, perhaps, would be the Neolithic burial in the Ille site, wherein two baler shell (Melo broderipii) scoops were found on top of human remains: one on the chest area and the other on the pelvis (UP-ASP 2005-2006). In other sites in Palawan (Fox 1970), the Bicol region (Fox and Evangelista 1956, 1957), and the Maitum site in Saranggani Province (Dizon and Santiago 1996), baler shell artefacts were found associated with other funerary items, such as burial jars. Even the unworked baler shells found in Tadyaw Cave in southern Palawan (Vitales 2009a), Kalanay site (Solheim 1964), and Maitum site (Dizon and Santiago 1996) were found in mortuary contexts. The presence of red pigments or colourants applied on several Melo artefacts from Ille and other Palawan sites were also observed, suggesting, again, the mortuary role of the shells. The colour red has a deep ritual significance in Philippine societies, both in the past and in the present (Fox 1970; Peralta 2000). Such pigments were mostly associated with mortuary practices in the past, usually found on human remains and other artefacts from burial sites (Fox 1970, 1977; Peralta 2000; Thiel 1986-87).

\section{The ritual role of baler shells}

Aside from their mortuary role, baler shells in the Philippines seem to have played some active part, as well, in particular ritual practices in the past, and this was observed in the Ille assemblage. While most of the breakage patterns found in the baler shell remains of Ille indicated working 
related to artefact production, there was also evidence of deliberate modification that seemed to be unrelated to artefact production. This type of breakage was first observed on some complete and partially complete artefacts, wherein the dorsal parts were punctured, most likely by a direct percussion technique, creating a perforation (Figure 10). Some dorsal fragments analysed also showed such patterns through evidence of semicircular notches, representing a total deviation from the natural fractural tendencies of these shells. Such practice of breaking or perforating the shell artefact closely resembled the ritual or ceremonial killing practice observed in other past and present cultures (Grinsell 1961; Leach 1976; Parker Pearson 1993), wherein they primarily apply this form of breaking to pottery. These breakage patterns on baler shell artefacts were also found in the neighbouring sites of Ille; furthermore, it seems this practice is confined to the northern Palawan region.
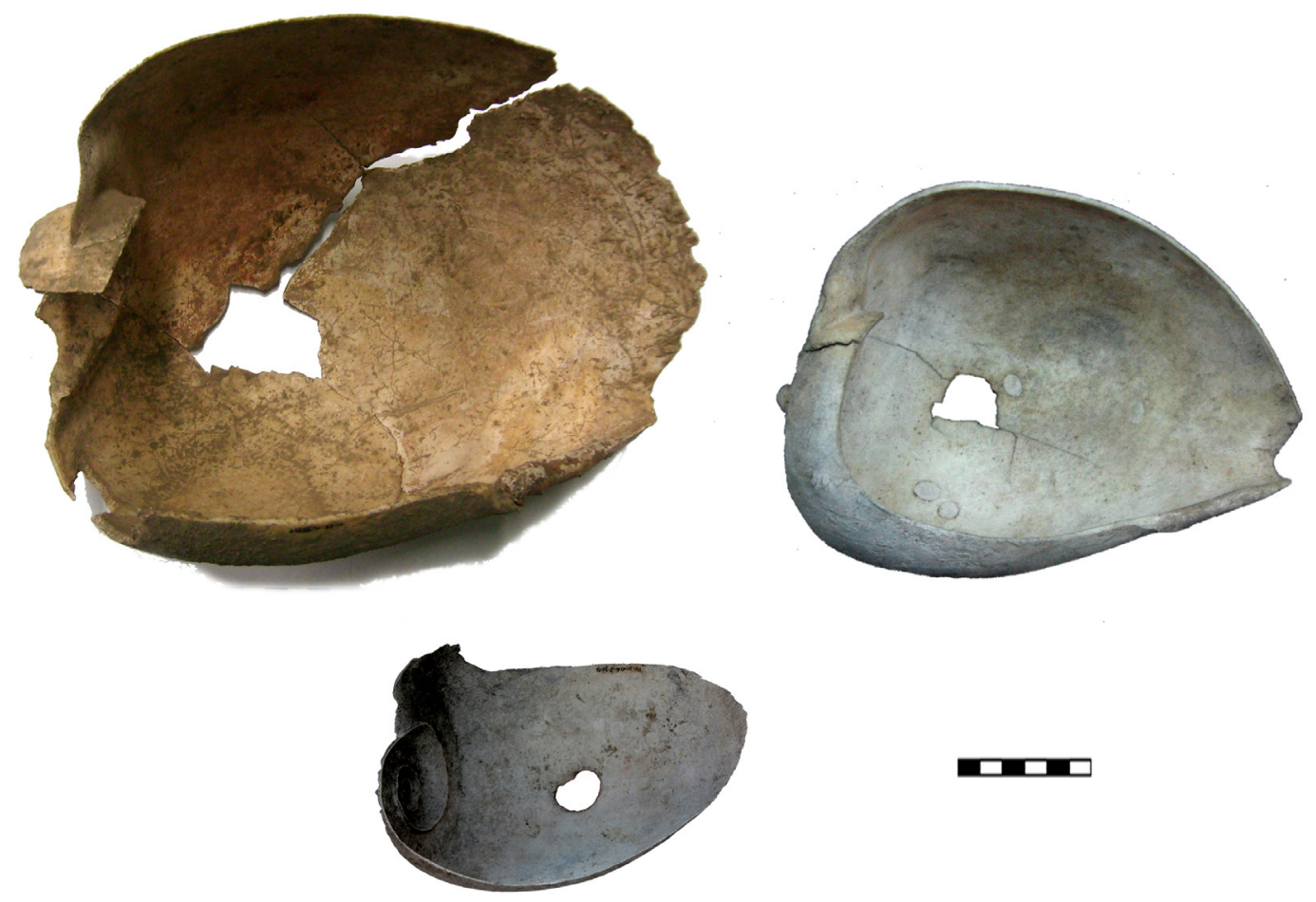

Figure 10. Baler shell scoops found within northern Palawan (including Ille site) with evidence of deliberate breakage. Scale in centimetres.

Source: Timothy Vitales.

This practice involving Melo shells has yet to be understood, and, therefore, further studies are needed to address such enquiries. On the other hand, it must be remembered that their inclusion in mortuary assemblages indicates a conscious or deliberate selection of these artefacts for burial purposes, which clearly reflects a particular cultural belief associated with this practice (Parker Pearson 1993). The possible practice of ceremonial killing involving baler shell scoops also indicates the special role of these materials in rituals and highlights their significance in society.

\section{Looking at the Bigger Picture: The Significance of Baler Shells as Raw Materials in the Indo-Pacific}

It is highly evident from the archaeological record that baler shells (Melo spp.) were among the molluscs selectively exploited during the Neolithic and Metal Ages in the Philippines. The results 
of the analyses from the baler shell assemblages at Ille and other Philippine sites clearly showed that most of these shells were actively selected primarily for artefact production (particularly in scoop forms), as evidenced by shell-working, as well as the post-mortem collection of some worked shells. Their inclusion in burial deposits also signified their particular role in mortuary and ritual practices in the past.

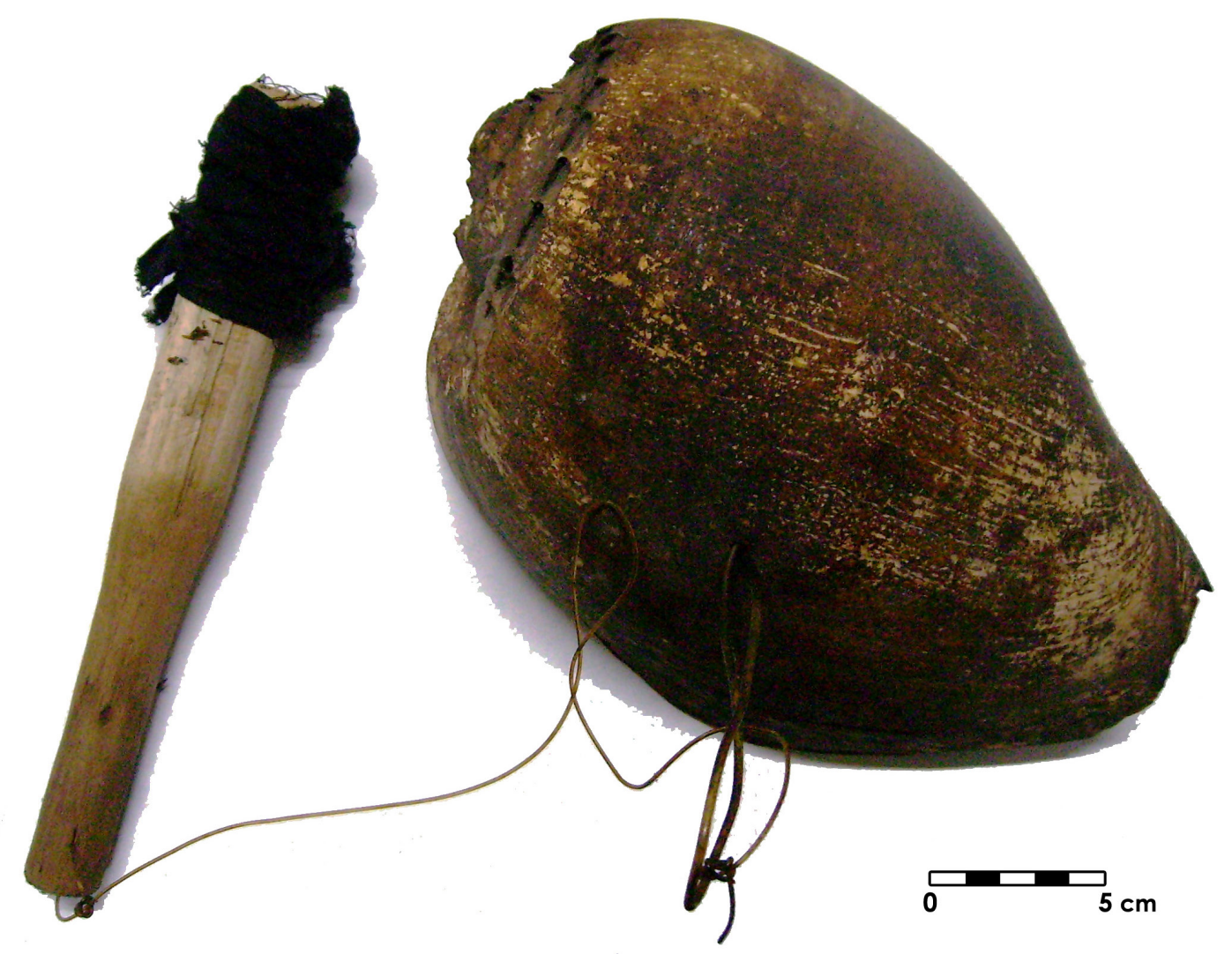

Figure 11. A baler shell 'gong' collected from a Pala'wan elder in southern Palawan.

Source: Timothy Vitales.

The significance of baler shells as raw materials in prehistory, however, is not confined to the Philippine archipelago. The selection of baler shells beyond subsistence purposes was apparently widespread in the Indo-Pacific. The 32,000-year-old baler shells (Melo amphora) found in northwest Australia are believed to have been utilised as value goods rather than food items (Brumm and Moore 2005; O'Connor and Chappel 2003; O'Connor and Veth 2000). This was also observed in other early sites in Australia (Bowdler 1999; O'Connor 1996, 1999; O'Connor and Veth 2000; Przywolnik 2003; Veth 1999). In a Hoabinhian site in Sumatra, baler shells (Melo melo) found in midden deposits were clearly worked, as evidenced by the perforated ventral faces of the shells' body whorls (see van Heekeren 1972). The baler shell remains in the Niah Caves Complex in Sarawak (Szabó et al. 2008) and in Vietnam (Szabó unpublished data) were modified into disc beads. Such examples of the shell's importance have also been observed ethnographically (see Introduction), attesting to the persistence of the conscious selection of baler shells for raw materials through to the ethnographic present.

In the Philippines, evidence for the exploitation of baler shells as raw materials seemed to have waned in the later periods, as shown in the archaeological record, but it has not disappeared entirely. Evidence of the post-mortem deposition of unworked Melo broderipii in the 17th to 
18th century site in Cebu City opened a window to the possibility of such exploitation around this period. As a matter of fact, baler shells were still utilised for several purposes during the ethnographic present. In southern Palawan, baler shells were sometimes used for ritual purposes as gongs by the Pala'wan group (Vitales 2009a) (Figure 11). Baler shells were also used as heirloom boat balers in Sulu, southern Philippines (R. Santiago pers. comm. 2007) and as cocoa crushers in the Visayan Islands (National Museum of the Philippines unpublished data).

Baler shell exploitation in the Indo-Pacific, especially in the Philippines, clearly indicates the special role of these shells in several cultures. Their significance, however, still needs to be explored to further understand the underlying conscious reasons for their acquisition and utilisation. It must be remembered that selection of particular shell taxa was not random. Through the practices of shell collecting, working, and utilisation, as inferred in the archaeological evidence, we might also understand how these shells were being perceived as food items, raw material, or even symbolic goods, and how such cultural knowledge is continuously being maintained, transformed, and transmitted through time.

\section{References}

Akerman, K. 1973. Aboriginal Baler Shell Objects in Western Australia. Mankind 9(2):124-125.

Akerman, K. 1975. Baler Shell Implements from North West Australia. Mankind 10(1):16-19.

Alba, E.D. 1998. Modified Bones and Shells from Philippine Archaeological Sites. National Museum Papers 8(1):45-80.

Archaeological, Cultural, and Environmental Consultancy, Inc (ACECI). 2006. Cebu Colonial Period Revisited: The Rescue Archaeology of Plaza Independencia. Unpublished report.

Bautista, A.P. 1988. The Exploitation of Animals in the Neolithic of the Philippines. Archaeozoologia 2(1-2):349-366.

Bowdler, S. 1999. Research at Shark Bay, WA, and the Nature of Coastal Adaptations in Australia. In J. Hall and I. McNiven (eds), Australian Coastal Archaeology, pp. 79-84. Canberra: The Australian National University.

Brumm, A. and M.W. Moore. 2005. Symbolic Revolutions and the Australian Archaeological Record. Cambridge Archaeological Journal 15(2):157-175.

Chen, C.-L. 1969. Material Culture of the Formosan Aborigines. Republic of China: The Taiwan Museum.

Dizon, E.Z. and R.A. Santiago. 1996. Faces from Maitum: The archaeological excavation of Ayub Cave. Manila: National Museum of the Philippines.

Faylona, M.G.P.G. 2003. A Preliminary Study on Shells from Ille Rock Shelter. Hukay 5:31-49.

Fox, R.B. 1970. The Tabon Caves: Archaeological explorations and excavations on Palawan Island, Philippines. Manila: National Museum of the Philippines.

Fox, R.B. 1977. Leta-Leta Cave: The science and art of cave archaeology. In A.R. Roces (ed.) Filipino Heritage: The Making of a Nation, vol. 1, pp. 228-234. Manila: Lahing Pilipino Publishing Inc.

Fox, R.B., and A. Evangelista. 1956. The Bato Caves, Sorsogon Province, Philippines: A preliminary report of a jar burial - stone tool assemblage. Unpublished report. Manila: National Museum of the Philippines.

Fox, R.B. and A. Evangelista. 1957. The Cave Archaeology of Cagraray Island, Albay Province, Philippines: A preliminary report of explorations and excavations. Unpublished report. Manila: National Museum of the Philippines. 
Grinsell, L.V. 1961. The Breaking of Objects as a Funerary Rite. Folklore 72(3):475-491.

Guthe, C.E. n.d. The University of Michigan Philippine Expedition: Field Catalog 1922-1925. Ann Arbor: University of Michigan.

Hughes, I. 1977. New Guinea Stone Age Trade. Canberra: The Australian National University. Terra Australis 3.

Irwin, G. 1985. The Emergence of Mailu. Canberra: The Australian National University. Terra Australis 10.

Kress, J.H. 2000. The Malacoarchaeology of Palawan Island. Journal of East Asian Archaeology 2(12):285-328.

Leach, E. 1976. Culture and Communication: The logic by which symbols are connected. Cambridge: Cambridge University Press.

Lewis, H., V. Paz, M. Lara, H. Barton, P. Piper, J. Ochoa, T. Vitales, A. J. Carlos, L. Neri, V. Hernandez, J. Stevenson, E.C. Robles, A. Ragragio, R. Padilla, W. Solheim, and W. Ronquillo. 2008. Terminal Pleistocene to Mid Holocene Occupation and an Early Cremation Burial at Ille Cave, Palawan, Philippines. Antiquity 82(316):318-335.

Lewis, H., V.J. Paz, J.H. Kress, M.G. Lara, J.G.L. Medrana, A.J. Carlos, P. Piper, V. Hernandez, H. Barton, E. Robles, T.J. Vitales, A. Ragragio, W.G. Solheim, and W. Ronquillo. 2006. Early Occupation at Ille Cave, New Ibajay, El Nido, Palawan, Philippines: Report on the 2005 excavation season. Report submitted to the British Academy, NERC/Orads, and the National Museum of the Philippines.

McCarthy, F.D. 1967. Australian Aboriginal Stone Implements. Sydney: The Australian Museum.

McCarthy, F.D., and F.M. Setzler. 1960. The Archaeology of Arnhem Island. Records of the AmericanAustralian Scientific Expedition to Arnhem Land 2:215-295.

Morse, K. 1993. New Radiocarbon Dates from North West Cape, Western Australia: A Preliminary Report. In M.A. Smith, M. Spriggs, and B. Fankhauser (eds), Sahul in Review, pp. 155-163. Canberra: The Australian National University.

Mulvaney, J. and J. Kamminga. 1999. Prehistory of Australia. Washington: Smithsonian Institution Press.

Nishimura, M. 1992. The Role of Long Distance Trade in the Development of Complex Societies. Unpublished doctoral dissertation. University of Michigan.

O'Connor, S. 1996. Where are the Middens? - An overview of the archaeological evidence for shellfish exploitation along the Northwestern Australian coastline. Indo-Pacific Prehistory Association Bulletin 15:165-180.

O'Connor, S. 1999. 30,000 Years of Aboriginal Occupation: Kimberly, North-west Australia. Canberra: The Australian National University.

O'Connor, S. and J. Chappell. 2003. Colonisation and Coastal Subsistence in Australia and Papua New Guinea: Different timing, different modes. In C. Sand (ed), Pacific Archaeology: Assessments and Prospects. Proceedings of the International Conference for the 50th Anniversary of the First Lapita Excavation (July 1952), Koné-Nouméa 2002, pp. 15-32. Nouméa: Le Cahiers de l'Archéologie en Nouvelle-Calédonie 15.

O'Connor, S. and P. Veth. 2000. The World's First Mariners: Savannah dwellers in an island continent. In S. O'Connor and P. Veth (eds), East of Wallace's Line: Studies of past and present maritime cultures of the Indo-Pacific region, vol. 16,Modern Quaternary Research in Southeast Asia, pp. 99-137. Rotterdam: A.A. Balkema. 
Paz, V.J. 1998. Archaeological Survey of El Nido, Palawan: with ethnographic notes May 3 to 14, 1998. Unpublished fieldnotes. Quezon City: Archaeological Studies Program, University of the Philippines.

Paz, V., W. Ronquillo, H. Lewis, P. Piper, J. Carlos, E. Robles, V. Hernandez, T. Vitales, J. Ochoa, T. Reyes, and H. Xhauflair. 2008. Palawan Island Palaeohistoric Research Project: Report on the 2008 Dewil Valley field season. Report submitted to the University of the Philippines-Archaeological Studies Program and the National Museum of the Philippines.

Paz, V., A. Ragragio, E. Robles, and M. Oxenham. 2008. The Catanauan Archaeological and Heritage Project: Report on the excavation of Napa site, Locality 1 and 2, Catanauan, Bondoc Peninsula, Quezon Province. Report submitted to the University of the Philippines-Archaeological Studies Program and the National Museum of the Philippines.

Parker Pearson, M. 1993. The Powerful Dead: Archaeological relationships between the living and the dead. Cambridge Archaeological Journal 3:203-229.

Peralta, J.T. 2000. The Tinge of Red: Prehistory of art in the Philippines. Manila: National Commission for Culture and the Arts.

Przywolnik, K. 2003. Shell Artefacts from Northern Cape Range Peninsula, Northwest Western Australia. Australian Archaeology 56:12-21.

Roales, T.M. 1985. Pupog Burial Rockshelter: Preliminary Report. National Museum of the Philippines.

Santiago, R.A., and A. Barbosa. 1977. Archaeological Exploration in Suluan Island, Samar. Leyte-Samar Studies 11(2):52-56.

Schall, A. 1985. Aboriginal Use of Shell on Cape York Peninsula. Brisbane: Archaeology Branch, Department of Community Services. Cultural Resource Management Monograph 6.

Shnukal, A. 2004. The Post-Contact Created Environment in the Torres Strait Central Islands. Memoirs of the Queensland Museum, Cultural Heritage Series 3(1):317-346.

Solheim, W.G. II. 1964. The Archaeology of Central Philippines: A Study chiefly of the Iron Age and its relationships. Manila: National Institute of Science and Technology.

Solheim, W.G. II. 2004. Excavations of Ille Rock Shelter, Palawan, Philippines (Preliminary Report). National Museum of the Philippines.

Springsteen, F.J. and F.M. Leobrera. 1986. Shells of the Philippines. Manila: Carfel Seashell Museum.

Szabó, K. 2005. Technique and Practice: Shell-working in the Western Pacific and Island Southeast Asia. Unpublished doctoral dissertation. The Australian National University.

Szabó, K. 2008. Shell as a Raw Material: Mechanical properties and working techniques in the tropical Indo-West Pacific. Archaeofauna 17:125-138.

Szabó, K., P.J. Piper, and G. Barker. 2008. Sailing Between Worlds: The Symbolism of death in northwest Borneo. In G. Clark, F. Leach, and S. O'Connor (eds), Islands of Inquiry: Colonisation, seafaring and the archaeology of maritime landscapes, pp. 149-170. Canberra: The Australian National University. Terra Australis 29.

Thiel, B. 1986-87. Excavations at Arku Cave, Northeast Luzon, Philippines. Asian Perspectives 27(2):229-264.

Thomson, D.F. 1934. The Dugong Hunters of Cape York. The Journal of the Royal Anthropological Institute of Great Britain and Ireland 64:237-263.

Tindale, N.B. 1977. Further Report on the Kaiadilt People of Bentinck Island, Gulf of Carpentaria Queensland. In J. Allen, J. Golson, and R. Jones (eds), Sunda and Sahul: Prehistoric Studies in 
Southeast Asia, Melanesia and Australia, pp. 247-274. London: Academic Press.

University of the Philippines-Archaeological Studies Program (UP-ASP). 2005-2006. Report on the Archaeological Investigation of Dewil Valley, New Ibajay, El Nido, Palawan. Unpublished report. Quezon City: University of the Philippines

van Heekeren, H.R. 1972. The Stone Age of Indonesia (revised edition). The Hague: Martinus Nijhoff.

Vanderwal, R. 2004. Early Historical Sources for the Top Western Islands in the Western Torres Strait Exchange Network. Memoirs of the Queensland Museum, Cultural Heritage Series 3(1):257-270.

Vermeij, G.J. 1993. A Natural History of Shells. New Jersey: Princeton University Press.

Veth, P., M. Spriggs, S. O'Connor, and A.D. Saleh. 2005. Wangil Midden: A late prehistoric site, with remarks on ethnographic pottery making. In S. O'Connor, M. Spriggs, and P. Veth (eds), The Archaeology of the Aru Islands, Eastern Indonesia, pp. 95-124. Canberra: The Australian National University. Terra Australis 22.

Vitales, T. 2009a. Form, Function, and Meaning: An Approach in Understanding Melo Shell Artefacts in Philippine Sites. Unpublished master's thesis. University of the Philippines.

Vitales, T. 2009b. Melo Shells in Philippine Archaeology. Paper presented during the Wilhelm G. Solheim II Foundation meeting on March 14, 2009 in Ortigas Center, Pasig City.

Weaver, C.S. and J.E. duPont. 1970. Living Volutes: A monograph of the recent Volutidae of the world. 